\title{
The California Current System as a transmitter of millennial scale climate change on the northeastern Pacific margin from 10-50 ka
}

\author{
M.A. Taylor ${ }^{\mathrm{a}}$, I.L. Hendya , D.K. Pak ${ }^{\mathrm{b}}$ \\ a Department of Earth and Environmental Sciences, University of Michigan, Ann \\ Arbor, MI 48109 \\ b Marine Science Institute, University of California, Santa Barbara, CA 93106
}

\begin{abstract}
A high resolution record of $\delta^{18} \mathrm{O}$ and $\mathrm{Mg} / \mathrm{Ca}$-based temperatures spanning
\end{abstract} $10-50 \mathrm{ka}$ has been reconstructed from the Vancouver margin of the northeastern

Pacific Ocean (MD02-2496) from two planktonic foraminiferal species,

Neogloboquadrina pachyderma (s.) and Globigerina bulloides. While $\delta^{18} \mathrm{O}_{\text {calcite }}$

appears synchronous with Dansgaard-Oeschger Interstadials (DOIs) throughout the

record, millennial scale variability in sea surface temperatures (SSTs) and

reconstructed $\delta^{18} \mathrm{O}_{\text {seawater }}$ are frequently out of phase with Greenland climate.

Changes in water mass characteristics such as $\delta^{18} \mathrm{O}_{\text {calcite }}$ and enriched $\delta^{15} \mathrm{~N}$

events apparently responded to millennial-scale climate change during Marine

Isotope Stage 3 (MIS 3), such that negative $\delta^{18} 0_{\text {calcite }}$ excursions coincided with

heavier $\delta^{15} \mathrm{~N}$. These water mass characteristic shifts are suggestive of the presence

of surface water advected from the Eastern Tropical North Pacific (ETNP) by

relative strengthening of the California Undercurrent (CUC) bringing warm, salty

tropical waters poleward. The linkage between the strength of the CUC on the NE This is the author manuscript accepted for publication and has undergone full peer review but has not been through the copyediting, typesetting, pagination and proofreading process, which may lead to differences between this version and the Version of Record. Please cite this article as doi: 10.1002/2014PA002738

This article is protected by copyright. All rights reserved. 
Pacific margin and millennial-scale climate change may be related to increased sea surface heights off Central America as the Intertropical Convergence Zone (ITCZ) shifted northward in response to changes in North Atlantic Ocean

circulation. Poor correlations between proxies exist through late MIS 3 into MIS 2.

Ice sheet growth could have disrupted the linkage between CUC and the NE Pacific margin as the Laurentide Ice sheet disrupted atmospheric circulation and the Cordilleran Ice Sheet increasingly influenced regional paleoceanography.

\section{Introduction}

Reconstructions of oceanographic conditions on the northeastern Pacific margin during the last glacial interval have displayed a high coherence with abrupt millennial scale climate events recorded in the North Atlantic deep sea and Greenland ice cores (Behl and Kennett, 1996; Cannariato and Kennett, 1999; Hendy and Kennett, 2000; Seki et al., 2002; Hendy et al., 2004; Hendy and Pedersen, 2005; Chang et al., 2008; Hendy and Cosma, 2008; Hendy, 2010; Pak et al., 2012; Ohkushi et al., 2014) despite their position distal to the LIS and regional North Atlantic climate forcing. Floral and faunal temperature proxies from ocean sediment cores at Santa Barbara Basin (Behl and Kennett, 1996; Hendy and Kennett, 2000), Point Conception (Seki et al., 2002; Hendy, 2010; Pak et al., 2012), Northern California (Mix et al., 1999), and Vancouver Island (Chang et al., 2008; Hendy and Cosma, 2008) display shifts suggesting warming during DOIs and cooling during stadials. Furthermore, changes in northeastern Pacific subsurface water mass characteristics (eg: warm and relatively salty waters during DOIs, cold and relatively fresh waters during stadials) and upwelling related productivity are also coherent with DOI 
events (Cannariato and Kennett, 1999; Hendy et al., 2004; Hendy and Pedersen, 2005; Chang et al., 2008; Chang et al., 2014; Ohkushi et al., 2014).

The mechanism responsible for SST/isotopic shifts in the extratropical North Pacific in response to DOI warming is not well understood, although the rapidity of the North Pacific oceanic response to the abrupt DOI climate events implicates $=$ atmospheric reorganization over the Pacific Ocean (Hendy and Kennett, 2000; Hendy et al., 2002). An atmospheric response can be linked to North Atlantic climate change via shifts in the ITCZ (Leduc et al., 2009; Okumura et al., 2009). Model simulations and proxy reconstructions indicate that cooling in the North Atlantic leads to a southward shift in the ITCZ, resulting in reduced precipitation in the North Pacific, while abrupt warming is associated with a northward movement of the ITCZ (Zhang and Delworth, 2005; Leduc et al., 2009; Denton et al., 2010;

Deplazes et al., 2013). Other Atlantic to Pacific Ocean basinal connections could be the result of anomalously cool westerly winds during North Atlantic stadials causing larger surface heat fluxes and southward Ekman transport in the central Pacific (Okumura et al., 2009), and/or relative changes in the strength of pressure systems such as the Arctic Low (Manabe and Stouffer, 1988).

\footnotetext{
$=$ Planktonic foraminiferal faunal and $\delta^{18} \mathrm{O}_{\text {calcite }}$ shifts during DOI climate events suggest that the northeastern Pacific Ocean surface waters responded to rapid climate change with a simple temperature response (Hendy et al., 2002). However, recent $\mathrm{Mg} / \mathrm{Ca}$-based SST reconstructions from planktonic foraminifera off California
} at ODP Site 1017 , revealed warming of $3^{\circ}$ to $7^{\circ} \mathrm{C}$ during DOI events that was also

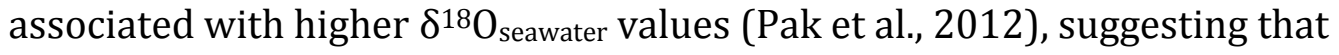


incursions of relatively warm and saline waters during interstadial warming in the North Atlantic could be ascribed to changes in the relative strength of the California Current System (CCS). Thus interstadials were associated with warm, high

$\delta^{18} \mathrm{O}_{\text {seawater }}$ water due to an increased contribution of saline, tropically sourced CUC water, while stadials were associated with increased contribution of fresh, subpolar $=$ water in the California Current System (CCS) (Pak et al., 2012).

Paired proxies to measure temperature and $\delta^{18} \mathrm{O}_{\text {seawater }}$ in paleoceanographic studies provide a powerful tool for reconstructing ocean circulation response to rapid climate change. The temperature-salinity characteristics of surface waters have been used as a conservative tracer to assess the modern ratio of ETNP to North Pacific water masses within the coastal current along North America with increasing temperature and salinity referred to as "spiciness" (Flament, 2002; Meinvielle and Johnson, 2013). Presently relatively warm, saline or spicy CUC water is detectable as far north as the Gulf of Alaska (Thomson and Krassovski, 2010), and is estimated to comprise up to $\sim 20-40 \%$ of the upper water column offshore of Vancouver Island (Meinvielle and Johnson, 2013). Additionally the $\delta^{15} \mathrm{~N}$ composition and oxygen concentration of ETNP oxygen minimum zone waters influence water mass characteristics along the coast of North America. In the modern ocean, low oxygen, denitrified water enriched in $\delta^{15} \mathrm{~N}$ moves northward from the ETNP via the CUC (Liu and Kaplan, 1989), and is associated with salinity maxima.

Here we investigate abrupt climate changes in the northern Northeast Pacific using the deep-sea core MD02-2496 (48 $58^{\prime} 47^{\prime \prime} \mathrm{N}, 127^{\circ} 02^{\prime} 14^{\prime \prime} \mathrm{W} ; 38.38 \mathrm{~m}$ core length; $1243 \mathrm{~m}$ water depth) retrieved from the continental slope, offshore from 
Vancouver Island, Canada. This sediment core represents the northernmost core site within the CCS yet studied, spanning the last $50 \mathrm{ka}$. High resolution planktonic foraminiferal $\delta^{18} \mathrm{O}_{\text {calcite }}$ (This study; Hendy and Cosma, 2008) and Mg/Ca based ocean temperature records were generated from the surface dwelling Globigerina bulloides and thermocline dwelling Neogloboquadrina pachyderma (sinistral). $\delta^{18} \mathrm{O}_{\text {seawater }}$ records for the two foraminiferal species have been generated using the coeval $\delta^{18} \mathrm{O}_{\text {calcite }}$ and $\mathrm{Mg} / \mathrm{Ca}$-based ocean temperature records in order to reconstruct SST and salinity changes connected with poleward undercurrent flow during the last glacial in association with millennial scale climate variability.

\subsection{Core site and modern setting}

The MD02-2496 core site lies within the transition zone between subtropical and subpolar gyral circulation, and is sensitive to changes in gyral strength and wind forcing, which may affect ocean temperatures by increased advection of surface waters or changes in upwelling regime (Freeland, 2006; Cummins and Freeland, 2007). The North Pacific Current (NPC) forms the northern branch of the North Pacific gyre, advecting colder, fresher surface waters from the western to the eastern North Pacific (Figure 1). The NPC bifurcates near the northeastern Pacific coast at $\sim 50^{\circ} \mathrm{N}$ latitude to form the Alaskan Coastal Current to the north and California Current to the south (Chelton and Davis, 1982). On the eastern boundary of the North Pacific Ocean, locally driven changes in ocean surface temperature and salinity are thought to be regulated primarily by the strengthening and weakening of the CCS, which makes up the eastern branch of the North Pacific gyre (Lynn and Simpson, 1987), and is driven by the strength and position of the NPH. The relative 
strength of the CCS/CUC is among the most important factors controlling variability in surface water characteristics along the Pacific margin. Wind field strength affects the amount of NPC entering the CCS from the north as well as the return flow of the CUC (Strub and James, 2002; Douglass et al., 2006; Freeland, 2006).

While the mechanisms for generating enhanced CUC flow are not fully

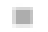
understood, sea surface height at the southern CCS boundary is known to be important (Connolly et al., 2014). In the modern climate system, the development of increased sea surface heights off Central America due to northward shifts in the ITCZ or Walker circulation result in enhanced poleward flow of surface waters in the northeastern Pacific originating in the tropics (Strub and James, 2002). Upwelling/wind stress along the California coast also strengthens the CUC significantly in the northern CCS, where increased upwelling at $\sim 40^{\circ} \mathrm{N}$ creates a steeper density gradient to the north, enhancing poleward undercurrent flow (Connolly et al., 2014). The North Pacific High (NPH) is thought to have strengthened and moved northward during DOIs, commensurate with more upwelling favorable winds (Hendy et al., 2004) and strengthened flow of the CUC (Hendy and Kennett, 2003). Thus multiple mechanisms exist that could drive the poleward flow of tropical surface waters in the northeastern Pacific during DOI climate events.

The modern annual average salinity at the site is $32.5 \mathrm{PSU}$, and average surface ocean temperature is $\sim 12^{\circ} \mathrm{C}$, ranging from $8^{\circ} \mathrm{C}$ in winter to $14^{\circ} \mathrm{C}$ in summer (Antonov et al., 2005; Locarnini et al., 2005). The summer season longshore coastal current system is composed of the California Current, the CUC, and the Vancouver 
Island Coastal Current (Masson and Fine, 2012). The central flow of the California Current is several hundred kilometers offshore, while the core of the poleward CUC flows over the continental slope, upwelling onto the shelf (Strub and James, 2002).

Seasonal upwelling occurs after the spring transition when wind forcing changes direction from southerly in winter to northerly dominance in summer around June$=$ July (Hickey and Banas, 2008). Modern nearshore currents on the continental shelf are driven by buoyancy forcing due to freshwater input from the Fraser River into the Georgia and Juan de Fuca Straits (Masson and Cummins, 1999). Fresh waters are tidally mixed with ocean currents entering the Straits, and this relatively buoyant water flows northward out of the Straits over the continental shelf, forming the Vancouver Island Coastal Current system (Cummins and Masson, 2014).

\section{Methods}

\subsection{Core Chronology}

Samples were analyzed at 5-10 cm intervals from 695 (uncorrected) to 3835 $\mathrm{cm}$ below core top in MD02-2496. Resolution of the $5 \mathrm{~cm}$ intervals ranges from $\sim 15$ to 160 years as a result of changing sedimentation rate within the core; the sedimentation rate is highest during the deglacial (15-20 ka).

Core chronology was established by Cosma et al., (2008), and is based upon forty-seven mixed planktonic foraminiferal and bulk organic carbon radiocarbon dates. The original chronology has been modified using the MARINE13 calibration (Reimer et al., 2013) generating a new calendar year based chronology (Taylor et al., 2014). Age model errors were estimated using a Bayesian model, Bacon 2.2 (Blaauw and Christen, 2011) and range from $\pm \sim 0.2$ to $2 \mathrm{ka}$ (Figure 2). A constant regional 
reservoir correction $(\Delta \mathrm{R})$ of $402.7 \pm 50$ years was assumed (Robinson and Thompson, 1981). Greenland climate events date assignments were made according to Blockley et al. (2012).

\subsection{Stable isotope and $\mathrm{Mg} / \mathrm{Ca}$ analysis}

Oxygen isotope analyses were performed on the surface dwelling

forâminifera G. bulloides. Samples consisting of planktonic foraminiferal species $G$. bulloides were picked from the $>125 \mu \mathrm{m}$ fraction, and $190 \mathrm{G}$. bulloides samples were prepared using standard techniques for stable isotope analysis. Samples were baked at $200^{\circ} \mathrm{C}$ under vacuum for 1 hour and dissolved at $76^{\circ} \mathrm{C}$ with anhydrous phosphoric acid in a Finnigan MAT Kiel device for analysis in a Finnigan MAT 251 triple collector isotope ratio mass spectrometer at the University of Michigan Stable Isotope Laboratory. Machine precision was $<0.1 \%$ and replicate $\delta^{18} 0$ values yielded a mean standard deviation of $0.14 \%$ for G. bulloides and $0.15 \%$ for $N$. pachyderma (Hendy and Cosma, 2008). Samples are reported using standard $\delta$ notion relative to the Vienna Pee Dee Belemnite (VPDB) standard. Samples were analyzed for major and trace metals ( $\mathrm{Ca}, \mathrm{Mg}, \mathrm{Sr}, \mathrm{Fe}, \mathrm{Mn}$ ). Approximately 60 individual N. pachyderma (s.) and 25 G. bulloides were picked to achieve an average sample weight of $\sim 300 \mu \mathrm{g}$ for each analysis. Poor carbonate preservation in the organic carbon-rich Holocene prevented $\mathrm{Mg} / \mathrm{Ca}$ analysis for samples younger than 10 ka. Visual inspection prior to analysis confirmed that foraminifera were well preserved prior to the Holocene. Samples were weighed and crushed before undergoing cleaning of contaminant phases via a multi-step protocol involving clay removal, and oxidative and reductive steps (Martin and Lea, 2002). In 
this marginal environment, reductive cleaning is necessary to remove oxides potentially adsorbed after sedimentation. Although the reductive cleaning step can lead to sample loss due to dissolution, a cleaning study of $N$. dutertrei, which has a

similar shell ultrastructure to N. pachyderma, indicated that reductive cleaning results in little lattice bound Mg loss (Bian and Martin, 2010). Cleaned samples were =

analyzed for trace metals using a Thermo-Finnigan Element II high resolution ICPMS at the University of Michigan (Barker et al., 2003; Boyle and Keigwin, 1985;

Keigwin and Boyle, 1989). The analytical precision of Mg/Ca based on 43 replicate analyses of external consistency standards is $0.074 \mathrm{mmol} / \mathrm{mol}(1 \mathrm{\sigma})$. The analytical precision for $\mathrm{Mg} / \mathrm{Ca}$ splits (6 pairs), reflecting both analytical and sampleprocessing uncertainty is $0.16 \mathrm{mmol} / \mathrm{mol}(1 \sigma)$, corresponding to $1.5^{\circ} \mathrm{C}$ uncertainty. $22 \%$ of samples were rejected due to low sample recovery $(<10 \%)$, or high $\mathrm{Mn} / \mathrm{Ca}$ and $\mathrm{Fe} / \mathrm{Ca}$ ratios suggestive of sample contamination.

G. bulloides and N. pachyderma $\mathrm{Mg} / \mathrm{Ca}$ values were converted to temperatures using the Elderfield and Ganssen (2000) calibration equation derived from core-top samples over a latitudinal transect from $30^{\circ}$ to $60^{\circ} \mathrm{N}$. This calibration equation is based on multiple temperate and subpolar species (Mean annual temperature $8^{\circ}-22^{\circ} \mathrm{C}$ ) including both $G$. bulloides and N. pachyderma (s.):

$\mathrm{Mg} / \mathrm{Ca}=0.52 * \mathrm{e}^{\left(0.10^{*} \mathrm{Temperature}\right)} \quad\left( \pm 0.7^{\circ} \mathrm{C}\right.$ standard error $)$

While the error based on $\mathrm{Mg} / \mathrm{Ca}$ analysis is well constrained, the error associated with the pre-exponential and exponential constants in the $\mathrm{Mg} / \mathrm{Ca}$-temperature calibration are not. Propagation of this error would overwhelm any real variability in the temperature record. We therefore confine our error estimates to variance in 
the raw $\mathrm{Mg} / \mathrm{Ca}$ values, and while we assign absolute temperatures to these values, we emphasize here that we are most confident in the relative magnitude of changes rather than definitive temperature reconstructions. The effect of continental ice sheets on $\delta^{18} \mathrm{O}_{\text {seawater }}$ was corrected for using the stacked benthic isotopic records of Waelbroeck et al. (2002) and incorporating a full glacial-interglacial shift of 1.1\%o (Chappell and Shackleton, 1986; Schrag et al, 1996). 3. Results

3.1 N. pachyderma and G. bulloides stable isotopes The $\delta^{18} \mathrm{O}_{\text {calcite }}$ values recorded by both species of planktonic foraminifera are similar, showing decreased $(\sim 1 \%$ ) values during MIS 3 interstadials (Figure $3 \mathrm{H}$ and I). The average and ranges of the 2 species are statistically indistinguishable until 14.5 to 10 ka where the variability of G. bulloides increases, and the running standard deviation (calculated from a 1 kyr moving average) increases from 0.15 to
} 
0.50 (red standard deviation envelopes shown in Figure 3H). During the Bølling/Allerød, N. pachyderma $\delta^{18} \mathrm{O}_{\text {calcite }}$ values decrease from 3.2 to $1.5 \%$, increase to $2.5 \%$ during the Younger Dryas, and decrease to $1.7 \%$ moving into the Holocene (blue standard deviation envelopes shown in Figure 3I).

3.2 $\mathrm{Mg} / \mathrm{Ca}$ and ocean temperatures

$=$

N. pachyderma $\mathrm{Mg} /$ Ca values ranged between $0.59 \mathrm{mmol} / \mathrm{mol}$ at $31.9 \mathrm{ka}$ during Heinrich event 3, and $1.74 \mathrm{mmol} / \mathrm{mol}$ at 41.2 ka during DOI 10. G. bulloides $\mathrm{Mg} / \mathrm{Ca}$ values ranged between 0.79 after the Last Glacial Maximum (LGM) at $19.2 \mathrm{ka}$, and 1.74 during the deglacial at $18.4 \mathrm{ka}$. Due to low abundance in sampled intervals between 30-40 ka, the analytical resolution of the G. bulloides $\mathrm{Mg} / \mathrm{Ca}$ data set is too low to capture centennial scale variations. N. pachyderma were sufficiently abundant to be analyzed at centennial-scale resolution revealing a high degree of variability in $\mathrm{Mg} / \mathrm{Ca}$ values, $>1$ standard deviation (exceeds 0.2 ), between 46.7 to $46.2,41.2$ to $40,37.3$ to $36,34.7$ to $30.1,28.9$ to $27.7,25.8$ to $25,24.3$ to 22.9 and 14. 4 to 11.4 ka. Positive excursions of $>1$ standard deviation from mean temperatures occur in short ( $<100$ year) intervals (Figure 3B, C). These intervals of high variability, with the exception of 25.8-25 ka, coincide with DOIs (specifically DOI 12, 9, 8, 6, 5, 4, 3 and 2) and the Bølling/Allerød as measured in NGRIP (NGRIP members, 2004; Blockley et al., 2012).

Between 35 and $51 \mathrm{ka}$, anomalously warm ocean temperatures $\left(7-12^{\circ} \mathrm{C}\right)$ occur during DOI 7-13 (Figure 3D and E). From 24-35 ka, warm ocean temperatures are coincident with DOI 3-6, but also frequently occur during DO stadials. From 17$24 \mathrm{ka}$, ocean temperature variation is muted, and maximum ocean temperatures are 
cooler (mean value: $8.3^{\circ} \mathrm{C}$ ). Ocean temperatures warm after $17 \mathrm{ka}$, reaching a maximum of $\sim 11^{\circ} \mathrm{C}$ during the Bølling/Allerød warming at $14.8 \mathrm{ka}$, and then cooling to $3^{\circ} \mathrm{C}$ at 12.2 ka during the Younger Dryas.

3.3 Reconstructed $\delta^{18} \mathrm{O}_{\text {seawater }}$

Reconstructed $\delta^{18} \mathrm{O}_{\text {seawater }}$ (ice volume corrected) values are positively relatted to the record of ocean temperatures, where relatively light (heavy) values are coincident with cooler (warmer) ocean temperatures (Figure 3F, G). Values range from $1.21 \%$ to $-1.93 \%$ (N. pachyderma) and from $1.27 \%$ to $-0.89 \%$ ( $G$. bulloides). For comparison, modern surface $\delta^{18} \mathrm{O}_{\text {seawater }}$ in the northeastern Pacific varies between $0.2 \%$ in the ETNP, and $-0.3 \%$ on the California margin to $-1.0 \%$ offshore of Vancouver Island (LeGrande and Schmidt, 2006). The variability in $N$. pachyderma $\delta^{18} 0_{\text {seawater }}$ from one sample interval to the next is consistently lowest $(<0.4 \%$ ) between 25 and 15 ka (Figure 3G). Similarly G. bulloides variability is smaller during this interval although it is also low between 40 and $30 \mathrm{ka}$, probably as the G. bulloides record is poorly resolved through this interval due to insufficient specimens (Figure 3F).

\section{Discussion}

The preferential habitats of the two planktonic foraminiferal species, $G$. bulloides and N. pachyderma (s.), employed at MD02-2496 have not been directly observed within the Vancouver margin. Generally G. bulloides tolerate a wide temperature range $\left(6-26^{\circ} \mathrm{C}\right)$ and are found in surface waters, but also dominate during cool upwelling conditions (0-20 m; Kuroyanagi and Kawahata, 2004, Sautter and Thunell, 1989). This depth habitat is confirmed by measurements of $\mathrm{Mg} / \mathrm{Ca}$ 
and stable isotope geochemistry of G. bulloides in Southern California (Sautter and Thunell, 1989; Pak et al., 2004). N. pachyderma (s.) live within the pycnocline in the Japan sea, and is associated with ocean temperatures cooler than $8^{\circ} \mathrm{C}(\sim 20-40 \mathrm{~m}$;

Kuroyanagi and Kawahata, 2004). This species dominates the foraminiferal fauna in weakly stratified subpolar water (Reynolds and Thunell, 1986). While the $=$ calibration equations used actually reconstructs the temperature at which foraminiferal calcification occurred, for simplicity we will refer to calcification temperatures hereafter as sea surface temperatures (SSTs). At MD02-2496, the reconstructed temperatures of $G$. bulloides are an average of $2.5^{\circ} \mathrm{C}$ warmer than $N$. pachyderma (s.), although the standard deviation of both sets of temperatures ( $N$. pachyderma stdev $=2.1^{\circ} \mathrm{C}, \mathrm{G}$. bulloides stdev $=1.6^{\circ} \mathrm{C}$ ) frequently overlap, suggesting that the two species occupy a similar depth habitat or that the water column is weakly stratified (Figure 4). Additionally reconstructed SSTs from MD02-2496 are in good agreement with a shorter (0-16 ka) alkenone-based sea surface temperature record taken approximately $13 \mathrm{~km}$ to the southeast (JT96-09mc) (Kienast and McKay, 2001; Taylor et al., 2014). The ocean temperatures recorded off the Vancouver margin over 45 ka have a broad range $\left(1^{\circ}\right.$ to $\left.12^{\circ} \mathrm{C}\right)$ encompassing abrupt SST warming and glacial-interglacial climate change. For reference, the modern annual surface ocean temperature range recorded at the nearby Station Papa for the past 50 years is $8-14^{\circ} \mathrm{C}$ (http://www.pac.dfo-mpo.gc.ca/science/oceans/datadonnees/line-p/index-eng.html). 4.1 MD02-2496 record of millennial scale variability 
We compare records of $\delta^{18} 0$ calcite, reconstructed $\delta^{18} O_{\text {seawater, and }}$ reconstructed SST from MD02-2496 offshore from Vancouver Island, Canada, and a record to the south, ODP-1017E, offshore from Point Conception, CA (Pak et al., 2012). These records were smoothed (simple linear interpolation at 300-year intervals) in order to minimize the effects of outliers on interpretation of noisy records (Figure 4). SSTs and $\delta^{18} \mathrm{O}_{\text {seawater }}$ from MD02-2496 show relatively warm/saline surface conditions during DOIs 12, 11, and 9-10 (Figure 4F-G). Generally during this interval, SSTs are warming from $\sim 3-6^{\circ} \mathrm{C}$ to $6-8^{\circ} \mathrm{C}$, or an amplitude of $\sim 3^{\circ} \mathrm{C}$ (from the 300 -year resampling), which is consistent with records to the south at ODP-1017E where 300-year running average G. bulloides reconstructed SSTs warm from $\sim 7-8^{\circ} \mathrm{C}$ to $11-12^{\circ} \mathrm{C}$, or an amplitude of $4^{\circ} \mathrm{C}$ when resampled (Figure 4). Comparisons were also made between proxies at MD02-2496 using unit variance normalized data smoothed with a $1 \mathrm{kyr}$ running average. $\delta^{18} \mathrm{O}$ calcite Values are more negative during these DOIs, although the excursions are less

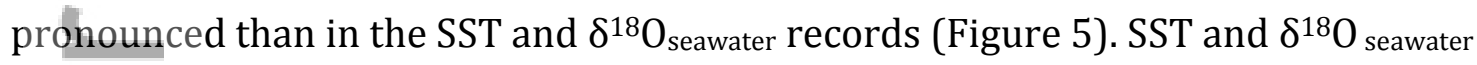
reconstructions show a weaker response than $\delta^{18} 0_{\text {calcite }}$ during DOI 8 with slightly warmer/more saline conditions (Figure 5).

The $\delta^{18} 0$ calcite record shows a sequence of 3 negative excursions during DOIs 6-7, that are smaller than those associated with previous DOIs, and increased values during Greenland stadial/H3 at 30 ka (Figure 5B). In contrast reconstructed SSTs and $\delta^{18} 0$ seawater show increased warming/salinity starting after DOI 7 ( $\left.\sim 35 \mathrm{ka}\right)$ that is sustained through 30 ka (Figure 5C-D). The SST shifts in N. pachyderma increase during this time to $5^{\circ} \mathrm{C}$, warming from an average of 3 to $8^{\circ} \mathrm{C}$, while the magnitude of 
SST increase does not change for G. bulloides at MD02-2496 or in ODP-1017, suggesting that either subsurface warming has increased or that the N. pachyderma record is noisier during this interval (Figure 4).

During DOIs 3-4 (30-25 ka), the $\delta^{18} \mathrm{O}_{\text {calcite }}$ decreased by $\sim 1 \%$ (Figure 5B)

while coeval SSTs and $\delta^{18} 0$ seawater suggest more variability occurred between relătively cool/fresh and weakly warm/saline surface ocean conditions (Figure 5CD). ${ }^{18} 0$ calcite increased and remained relatively stable from $\sim 25$ to $17 \mathrm{ka}$ (Figure 5B), while SSTs and $\delta^{18} \mathrm{O}_{\text {seawater indicate warming/higher salinity beginning at } 25 \mathrm{ka}}$ through H2 (Figure 5C-D), coincident with warming to $>12^{\circ}$ in the ODP-1017 SST record (Figure 4B-C). After DOI 2, at $\sim 20 \mathrm{ka}$, SSTs and $\delta^{18} \mathrm{O}_{\text {seawater indicate }}$ cool/fresher conditions off Vancouver Island, followed by a warming of $\sim 2^{\circ} \mathrm{C}$ during $\mathrm{H} 1$ followed by a second warming event of $\sim 2^{\circ} \mathrm{C}$ during the Bølling/Allerød (Figure 5C-D).Alkenone derived SSTs from the Okhotsk Sea in the subpolar northwestern Pacific show warming of 6-8 ${ }^{\circ} \mathrm{C}$ during DOIs occurring between 20-60 ka, although these SST anomalies were accompanied by surface ocean freshening that is not observed in the northeastern Pacific (Harada et al., 2008). $\delta^{18} \mathrm{O}_{\text {seawater }}$ records at MD02-2496 and ODP-1017 exhibit relatively large, high frequency isotopic shifts $(>0.4 \%$ ) that occur approximately twice per kyr in coherence with SST warming (Figure 4) (Pak et al., 2012). While these shifts are less frequent in the G. bulloides record, notably in the low resolution interval of the record, shifts in excess of $0.4 \%$ do persist (Figure 4). Although it might be argued that the variability in the $\delta^{18} 0$ seawater records is an artifact of the noisy SST record, large shifts $\left(>1 \%\right.$ ) $\delta^{18} 0_{\text {calcite }}$ that occur between $30-25$ ka support real variability in 
the SST and $\delta^{18} \mathrm{O}_{\text {seawater }}$ records (Figure 3H and I, 5B). Assuming a similar geographical $\delta^{18} \mathrm{O}_{\text {seawater }}$ distribution during the last glacial, $\delta^{18} \mathrm{O}_{\text {seawater }}$ shifts of $0.5 \%$ would imply waters coming from offshore Baja, CA, while larger shifts fall outside modern observations (Legrande and Schmidt, 2006).

Global scale mechanisms, such as expansion of sea ice in the northern North Pacific, could influence $\delta^{18} \mathrm{O}_{\text {seawater }}$ at MD02-2496. During the Heinrich 1 and Younger Dryas stadials, the sea-ice boundary was shifted southward in the Okhotsk and western Bering Seas (Max et al., 2013). Records in the Okhotsk Sea indicate millennial scale expansion of sea ice during stadials and sea surface freshening corresponding to interstadials extending back to the beginning of MIS 3 (Harada et al., 2008; Riethdorf et al., 2013). However, recent modeling suggests that the isotopic shifts from interglacial to glacial intervals due to sea ice expansion were small, increasing by $0.12 \%$ in the North Atlantic surface waters (Brennan et al., 2013).

Changes in the tropical hydrologic cycle in response to shifts in the average position of the ITCZ and intensity of the Asian monsoon could also influence $\delta^{18} \mathrm{O}_{\text {seawater }}$ at MD02-2496. Gibbons et al. (2014) estimate a shift in surface water $\delta{ }^{18} 0_{\text {seawăter }}$ during deglacial stadials of up to $\sim 0.6 \%$ in the eastern tropical Pacific via southward movement of the ITCZ resulting in decreased water vapor export from the Atlantic to the Pacific tropical basins and resulting in increased salinity in the eastern equatorial Pacific (Figure 5E) (Leduc et al., 2009; Leduc et al., 2010). $\delta^{18} \mathrm{O}_{\text {calcite }}$ values have been employed in a number of paleoceanographic studies to characterize DOI events in the North Pacific (Leduc et al., 2009; Kennett et al., 2000; 
Hendy and Kennett, 2000). Similarly the $\delta^{18} 0_{\text {calcite }}$ records of both G. bulloides and $N$. pachyderma at MD02-2496 demonstrate rapid climate variability that appears to be synchronous with DOIs (Hendy and Cosma, 2008) (Figure 3). $\delta^{18} \mathrm{O}_{\text {calcite }}$ at MD022496 appears to be influenced strongly by both temperature and changes in salinity, and $\delta^{18} 0_{\text {seawater }}$ shifts towards positive values often coincide with warmer ocean $=$

temperatures. Running cross correlations between SSTs and $\delta^{18} \mathrm{O}_{\text {calcite }}$ were calculated with a 2.4 ka moving window from resampled records (simple linear interpolation at 300 year intervals; Figure 6B). The most significant positive correlations occur between 37-47 ka (Figure 6). The positive temperature anomalies during the Bølling/Allerød occur slightly earlier than the negative $\delta^{18} 0_{\text {calcite }}$ anomalies, and so despite a similar visual appearance there is no strong correlation between the records at this time. This is possibly the result of lower SST sample resolution during the Bølling/Allerød relative to the $\delta^{18} 0_{\text {calcite }}$ record rather than a real mismatch in timing among the proxies.

There are clear differences in duration and magnitude of SST warming and

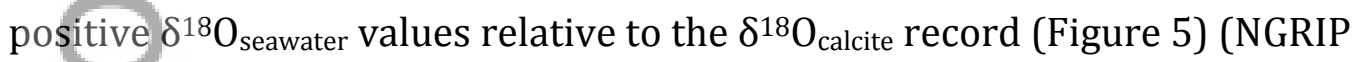
members, 2004). As large shifts in both salinity and temperature are implied in the SST reconstruction at MD02-2496, the $\delta^{18} 0_{\text {calcite }}$ record alone is insufficient to understand the surface water characteristics in the NE Pacific.

4.2 A spicy California Undercurrent water mass

The CUC is characterized as warm, salty (spicy), nutrient-rich, oxygen-poor waters in contrast with the California Current, which is cold, fresh, nutrient poor and oxygen rich (Meinvielle and Johnson, 2013). Contribution of tropically sourced 
waters from the CUC is another modern driver of decadal salinity variability along the Vancouver margin, where saline intermediate waters consisting of at least $30 \%$ ETNP waters advected poleward by the CUC are pumped to the surface via upwelling (Foreman et al., 2008; Thomson and Krassovski, 2010). With modern climate warming, increased ETNP water advection into higher latitudes via the CUC

has been established by observations of a sharp decrease in subsurface dissolved oxygen concentration and increase in spicy water along the west coast of North America between $25^{\circ}$ and $50^{\circ} \mathrm{N}$ latitude (Meinvielle and Johnson, 2013). This is consistent with both an increase in transport of the CUC, and shoaling of the core CUC such that a greater proportion of ETNP waters are upwelled onto the continental shelf (Meinvielle and Johnson, 2013).

High bulk sedimentary $\delta^{15} \mathrm{~N}$ values are produced by denitrification within the ETNP oxygen minimum zone, and carried northward with the CUC along the eastern Pacific margin, thereby operating as a proxy for the relative strength of the current (Kienast et al., 2002; Chang et al., 2008). The general coherence of the $\delta^{15} \mathrm{~N}$ records along the northeastern Pacific margin is suggestive of large-scale processes dominating the $\delta^{15} \mathrm{~N}$ signal (Kienast et al., 2002; Hendy et al., 2004; Chang et al., 2008; Galbraith et al., 2008). The CUC brings relatively denitrified, low oxygen spicy waters to the extratropics, with a core flow along the continental slope, upwelling onto the continental margin. Records on the North American margin have demonstrated coherence between millennial scale climate change and $\delta^{15} \mathrm{~N}$ of bulk sediments (Kienast et al., 2002; Chang et al., 2008; Hendy et al., 2004).), indicating that sediments were more enriched in ${ }^{15} \mathrm{~N}$ during DOIs of MIS 3 . This has been 
interpreted as a higher influx of ETNP-sourced, denitrified waters during DOIs, with the California Current System serving to physically link the ETNP to the northeastern Pacific from the Mexican margin as far north as the Vancouver Margin (Kienast et al., 2002; Galbraith et al., 2008; Chang et al., 2014; Hendy et al., 2004).

Comparison of normalized bulk sediment $\delta^{15} \mathrm{~N}$ at MD02-2496 with coincident SST and stable isotope samples provides a more robust identification of changes in CUC strength on the Vancouver margin (Figure 5E), where coeval enrichments in both MD02-2496 bulk sedimentary $\delta^{15} \mathrm{~N}$ (Chang et al., 2008) and negative $\delta^{18} \mathrm{O}_{\text {calcite }}$ values support increased ETNP advection to the Vancouver Margin. Running cross correlations between $\delta^{15} \mathrm{~N}$ and $\delta^{18} 0_{\text {calcite }}$ were calculated with a 2.4 ka moving window from resampled records (simple linear interpolation at 300 year intervals; Figure 6C). These records were strongly anti-correlated and significant correlations (>95\%) were calculated between 38-42 ka . 28-30 ka and after $\sim 14 \mathrm{ka}$. Therefore, enriched $\delta^{15} \mathrm{~N}$ values were associated with negative $\delta^{18} 0_{\text {calcite }}$ suggesting spicier water as a result of greater influence of CUC water in surface waters off Vancouver Island, CA. During the last deglaciation (15-17 ka) and the penultimate deglaciation after $45 \mathrm{ka}$, depletion in $\delta^{15} \mathrm{~N}$ at MD02-2496 resulted from increased terrestrial organic carbon flux to the sediments as the CIS retreated (Chang et al., 2014). Thus more enriched $\delta^{15} \mathrm{~N}$ values generally coincide with relatively warm SSTs/salinity, while depleted values occur during stadials (Figure 5). To the south, at ODP-1017E, millennial scale variability in surface waters through the last glacial was also dominated by changes in water mass spiciness (Hendy et al., 2004; Pak et al., 2012). These trends support the presence of the CUC 
during warm intervals earlier in the record, and then intermittent and less predictable CUC flow through the LGM as local ocean circulation dominated the glaciated Vancouver Margin.

There exist several possible mechanisms to drive strengthening of the CUC. A relationship between abrupt warming in the North Atlantic and northward $=$ movement of the ITCZ has been identified in paleoclimate records (Leduc et al., 2009; Deplazes et al., 2013), which may have enhanced the sea surface height at the southern boundary of the CCS, increasing poleward flow of the CUC. Upwelling is also associated with interstadials along the California margin and may serve to strengthen the CUC on the northern end of the CCS (Hendy et al., 2004). It is also possible that warm saline water may also be advected to the site via the North Pacific Drift (NPD). A SST reconstruction from the Northwestern Pacific (MD012404) exhibits warming during similar intervals after $30 \mathrm{ka}$, which has been attributed to dynamic heat transport of the Kuroshio Current in response to Antarctic warming (Chen et al., 2010). As the Kuroshio Current feeds into the NPD, this reconstruction provides an additional mechanism to explain warm saline water at MD02-2496, however, water advected via the NPD does not contain enriched $\delta^{15} \mathrm{~N}$.

\subsection{Local influences and conditions}

Regional influences on $\delta^{18} \mathrm{O}_{\text {seawater }}$ at MD02-2496 may offer one explanation

for the lack of coherency between MD02-2496 and other proxy records along the NE Pacific margin between 30 and $20 \mathrm{ka}$. These regional factors include changes in precipitation/evaporation balances and changes in ocean circulation, while local variability in the wind stresses could produce the high frequency temperature 
variability on the Vancouver margin during this interval. On the modern ice-free Vancouver Margin, fresh waters are tidally mixed with ocean currents entering the Straits, mixing with seasonally upwelled waters flowing onto the continental shelf (Cummins and Masson, 2014). However, the effect of the ice sheet growth during the interval from 30 to the LGM could have played an important role in overprinting global climate events. With the growth of the CIS, the buoyancy driven current system would not have existed in its modern form (Taylor et al, 2014). During the LGM grounded ice on the Vancouver Island continental shelf filled the straits (Mosher and Hewitt, 2004) where tidal mixing would have occurred. Grounded ice extended as far as the shelf break south of MD02-2496 $\left(\sim 49.5^{\circ} \mathrm{N}\right)$ where ice from the Juan de Fuca Strait and the Barkley Sound coalesced into a large piedmont glacial lobe.

Modern ocean temperatures in this region are also influenced by the latitudinal position of the NPC, which can vary considerably over short times scales $\left(\sim 8^{\circ}\right.$ latitude in 2002) as a result of stochastic wind forcing (Sydeman et al., 2011), leading to sea surface cooling of $\sim 1^{\circ} \mathrm{C}$ (Freeland et al., 2003). The average latitude of NPC bifurcation is $42-52^{\circ} \mathrm{N}$. Bifurcation of the NPC to the north of its average position results in enhanced advection of cool/fresh subarctic waters into the CCS (Sydeman et al., 2011). It is possible that the bifurcation of the NPC moved south as global climate cooled towards the LGM.

At present, variability in ocean temperatures and salinities along the Vancouver margin are in part a manifestation of noisy atmospheric forcing and coastal precipitation/runoff with SST and salinity anomalies ranging by $\pm 2\left({ }^{\circ} \mathrm{C}, \mathrm{PSU}\right)$ 
over the last 70 years (Cummins and Masson, 2014). Ocean temperature anomalies are significantly correlated with fall/winter wind stress, while local salinity is primarily controlled by fluctuations of coastal freshwater runoff (Cummins and Masson, 2014). The seasonal input of freshwater runoff changed dramatically as the Cordilleran Ice Sheet grew from 30 to the LGM as winter precipitation entered III

coastal waters during summer.

Thus, while seawater proxies on the Vancouver margin are recording broad scale changes in circulation via atmospheric reorganization during the last glacial, surface ocean characteristics such as salinity and temperature may also be subject to overprinting by very local processes such as variable inshore upwelling and freshwater runoff via meltwater.

4.4 North Atlantic and North Pacific teleconnections

Alternatively, the breakdown of coherency between North Atlantic and North Pacific climate teleconnections may be related to changes in large scale atmospheric circulation coincident with the growth of the LIS and CIS after 30 ka. Modeling studies have shown that ice sheet topography is a dominant factor altering northern hemisphere extratropical atmospheric circulation, and may change the strength and position of the subtropical jet, thereby altering storm tracks (COHMAP members, 1988; Pausata et al., 2011; Beghin et al., 2014). The westerly winds are posited as one method of teleconnection between the North Atlantic and North Pacific, communicating anomalous SSTs (COHMAP members, 1988; Timmerman et al., 2004). As North American ice sheets grew to maximum extent at the LGM, model results suggest that the westerlies could have weakened, causing a warming in the 
eastern North Pacific (COHMAP members, 1988; Timmermann et al., 2004). The topographic barrier formed by the LIS and the CIS alters atmospheric circulation in the North Pacific, Northern Canada, and Alaska during the LGM (Timmermann et al., 2004; Justino et al., 2005). This is coincident with apparent warming, independent from climate events in the North Atlantic, recorded by Mg/Ca-SSTs between 20 and $30 \mathrm{ka}$.

Recent observations of isotopic decoupling during the deglacial in the Gulf of Alaska showed that $\delta^{18} \mathrm{O}_{\text {calcite }}$ was inversely correlated with NGRIP $\delta^{18} 0$ from 18 to $16 \mathrm{ka}$, and then synchronized during the Bølling/Allerød and Holocene (Davies et al., 2011; Praetorius and Mix, 2014). Similarly at MD02-2496, Mg/Ca SSTs were decoupled from North Atlantic climate starting at $~ 30 \mathrm{ka}$, and after the LGM,

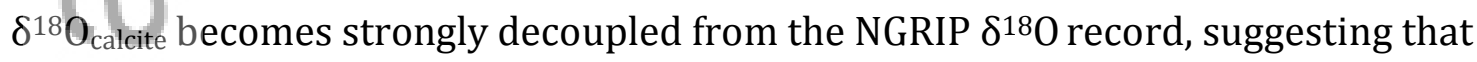
dynamic coupling between North Atlantic and North Pacific climate extends beyond the Gulf of Alaska.

\section{Conclusions}

A 50 ka record of N. pachyderma and G. bulloides $\delta^{18} \mathrm{O}_{\text {calcite }}$ and $\mathrm{Mg} / \mathrm{Ca}$-based SSTs from the Vancouver margin (MD02-2496) (Hendy and Cosma, 2008), reveals a complex relationship between isotopic and SST records. Large shifts of up to $0.5 \%$ were recorded in $\delta^{18} \mathrm{O}_{\text {seawater. If the geographical }} \delta^{18} \mathrm{O}_{\text {seawater }}$ distribution during the last glacial was similar to the modern, $\delta^{18} \mathrm{O}_{\text {seawater }}$ increases of $0.5 \%$ would imply waters coming from offshore Baja, CA, but larger positive shifts cannot be explained by advection of tropical waters alone. At MD02-2496 and ODP-1017, large variability in the reconstructed SST records show that on the NE Pacific margin 
$\delta^{18} \mathrm{O}_{\text {calcite }}$ records alone may not be sufficient to resolve simultaneous temperature and salinity shifts.

Millennial-scale $\delta^{18} \mathrm{O}_{\text {calcite }}$ excursions frequently coincided with positive anomalies in the $\delta^{15} \mathrm{~N}$ record, indicating a strong association between water mass spiciness and denitrification. These changes in water mass characteristics are suggestive of increased transport of waters from the Eastern Tropical North Pacific via the California Undercurrent (CUC). Higher $\delta^{15} \mathrm{~N}$ values are recorded in sediment cores along the NE Pacific margin, suggestive of temporally coherent, large scale changes in the California Current System (CCS) and transport of tropical water northward (Kienast et al., 2002; Chang et al., 2008; Galbraith et al., 2008). Previous studies indicate a strong teleconnection between North Atlantic climate forcing, and the position of the Intertropical Convergence Zone (ITCZ) in the tropical North Pacific (Leduc et al., 2009; Okumura et al., 2009; Leduc et al., 2010; Deplazes et al., 2013). This may result in an increase in the relative strength of the CUC during SST warming. CUC strengthening could have developed as sea surface heights increased at the southern end of the CCS when the ITCZ was displaced northward. Modeling indicates that by late MIS 3, ice sheet growth at mid- and high latitudes increasingly impacted northern hemisphere atmospheric circulation patterns. The interval between $\sim 20-33$ ka is poorly correlated at times between

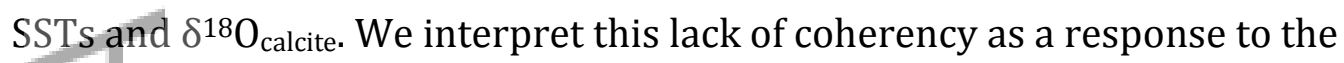
increasing influence of regional climate change on seawater geochemistry as Cordilleran Ice Sheet growth changed local surface ocean circulation, temperature and the timing and composition of freshwater input (Taylor et al., 2014). 
Additionally the vertical expansion of the Laurentide Ice Sheet topography impacted westerly wind strength, causing SST anomalies in the North Pacific (Timmermann et al., 2004; Justino et al., 2005). At the Bølling/Allerød (14.7 ka), proxies for increased advection of ETNP sourced water mass become coherent once again.

\section{Acknowledgements}

$=$

This research was supported with funds from the Elizabeth C. Crosby Research Fund Grant \# U038916, Rackham Graduate Student Research Grant \# U035598, and the Scott Turner Award through the University of Michigan. We thank the 2002 shipboard party of the MD126/IMAGES VIII (MONA) cruise of the R/V Marion Dufresne operated by the French Polar Institute (IPEV). We would like to thank David Lea at University of California, Santa Barbara for access to laboratory training and Ted Huston at the University of Michigan Keck Laboratory for technical assistance. Supplemental data are available at Pangaea (http://www.pangaea.de/). 


\section{References}

Auad, G., D. Roemmich, and J. Gilson (2011), The California Current System in relation to the Northeast Pacific Ocean circulation, Progress In Oceanography, 91(4), 576-592.

Barker, S., M. Greaves, and H. Elderfield (2003), A study of cleaning procedures used $=$ for foraminiferal Mg/Ca paleothermometry, Geochemistry Geophysics Geosystems, 4(9), 8407.

Beghin, P., S. Charbit, C. Dumas, M. Kageyama, D. M. Roche, and C. Ritz (2014), Interdependence of the growth of the Northern Hemisphere ice sheets during the last glaciation: the role of atmospheric circulation, Climate of the Past, 10(1), 345-358.

Behl, R. J., and J. P. Kennett (1996), Brief interstadial events in the Santa Barbara basin, NE Pacific, during the past 60 kyr, Nature, 379(18), 243-246.

Bian, N., and P. A. Martin (2010), Investigating the fidelity of Mg/Ca and other elemental data from reductively cleaned planktonic foraminifera, Paleoceanography, 25(2), PA2215.

Blaauw, M., and J. A. Christen (2011), Flexible paleoclimate age-depth models using an autoregressive gamma process. Bayesian Analysis 6, 457-474.

Blockley, S. P. E., et al. (2012), Synchronisation of palaeoenvironmental records over the last 60,000 years, and an extended INTIMATE1 event stratigraphy to 48,000 b2k, Quaternary Science Reviews, 36(C), 2-10.

Boyle, E. A., and L. D. Keigwin (1985), Comparison of Atlantic and Pacific paleochemical records for the last 215,000 years: changes in deep ocean 
circulation and chemical inventories, Earth and Planetary Science Letters, 76, $135-150$.

Brennan, C. E., K. J. Meissner, M. Eby, C. Hillaire-Marcel, and A. J. Weaver (2013),

Impact of sea ice variability on the oxygen isotope content of seawater under glacial and interglacial conditions, Paleoceanography.

Cannariato, K. G., and J. P. Kennett (1999), Climatically related millennial-scale fluctuations in strength of California margin oxygen-minimum zone during the past 60 k.y., Geology, 27, 975-978.

Chang, A. S., T. F. Pedersen, and I. L. Hendy (2008), Late Quaternary paleoproductivity history on the Vancouver Island margin, western Canada: a multiproxy geochemical study, Canadian Journal of Earth Sciences, 45(11), 1283-1297.

Chang, A. S., T. F. Pedersen, and I. L. Hendy (2014), Effects of productivity, glaciation and ventilation on late Quaternary sedimentary redox and trace element accumulation on the Vancouver Island margin, western Canada, Paleoceanography, 29, PA002581.

Chappell, J., and N. J. Shackleton (1986), Oxygen isotopes and sea level, Nature, 324, 137-140.

Chelton, D. B., and R. E. Davis (1982), Monthly mean sea-level variability along the west coast of North America, Journal of Physical Oceanography, 12, 757-784. Chen, M. T., X. P. Lin, Y. P. Chang, Y. C. Chen, L. Lo, C. C. Shen, Y. Yokoyama, D. W. Oppo, W. G. Thompson, and R. Zhang (2010), Dynamic millennial-scale 
climate changes in the northwestern Pacific over the past 40,000 years, Geophysical Research Letters, 37(23), L23603.

COHMAP (1988), Climatic Changes of the Last 18,000 Years: Observations and Model Simulations, Science, 241(4869), 1043-1052.

Connolly, T. P., B. M. Hickey, I. Shulman, and R. E. Thomson (2014), Coastal Trapped $=$

Waves, Alongshore Pressure Gradients, and the California Undercurrent*, Journal of Physical Oceanography, 44(1), 319-342.

Cosma, T. N., I. L. Hendy, and A. S. Chang (2008), Chronological constraints on Cordilleran Ice Sheet glaciomarine sedimentation from core MD02-2496 off Vancouver Island (western Canada), Quaternary Science Reviews, 27(9-10), 941-955.

Cummins, P. F., and H. J. Freeland (2007), Variability of the North Pacific Current and its bifurcation, Progress In Oceanography, 75(2), 253-265.

Cummins, P. F., and D. Masson (2014), Climatic variability and trends in the surface waters of coastal British Columbia, Progress In Oceanography, 120(C), 279290.

Davies, M. H., A. C. Mix, J. S. Stoner, J. A. Addison, J. Jaeger, B. Finney, and J. Wiest (2011), The deglacial transition on the southeastern Alaska Margin:

Meltwater input, sea level rise, marine productivity, and sedimentary anoxia, Paleoceanography, 26(2), PA2223.

Denton, G. H., R. F. Anderson, J. R. Toggweiler, R. L. Edwards, J. M. Schaefer, and A. E. Putnam (2010), The Last Glacial Termination, Science, 328(5986), 1652-1656. 
Deplazes, G., et al. (2013), Links between tropical rainfall and North Atlantic climate during the last glacial period, Nature Geoscience, 6(3), 213-217.

Douglass, E., D. Roemmich, and D. Stammer (2006), Interannual variability in northeast Pacific circulation, Journal of Geophysical Research, 111(C4), C04001.

Elderfield, H., and G. Gannsen (2000), Past temperature and d180 of surface ocean waters inferred from foraminiferal $\mathrm{Mg} / \mathrm{Ca}$ ratios, Nature, 405, 442-445.

Flament, P. (2002), A state variable for characterizing water masses and their diffusive stability: spiciness. Progress In Oceanography 54, 493-501.

Foreman, M. G. G., W. Callendar, A. MacFadyen, B. M. Hickey, R. E. Thomson, and E. Di Lorenzo (2008), Modeling the generation of the Juan de Fuca Eddy, Journal of Geophysical Research, 113(C3), C03006.

Freeland, H. J. (2003), Cold halocline in the northern California Current: An invasion of subarctic water, Geophysical Research Letters, 30(3), 1141.

Freeland, H. J. (2006), What Proportion of the North Pacific Current Finds its Way into the Gulf of Alaska?, Atmosphere-Ocean, 44(4), 321-330.

Galbraith, E. D., M. Kienast, S. L. Jaccard, T. F. Pedersen, B. G. Brunelle, D. M. Sigman, and T. Kiefer (2008), Consistent relationship between global climate and surface nitrate utilization in the western subarctic Pacific throughout the last 500 ka, Paleoceanography, 23(2), PA001518.

Gibbons, F. T., D. W. Oppo, M. Mohtadi, Y. Rosenthal, J. Cheng, Z. Liu, and B. K. Linsley (2014), Deglacial $\delta 180$ and hydrologic variability in the tropical Pacific and Indian Oceans, Earth and Planetary Science Letters, 387, 240-251. 
Harada, N., M. Sato, and T. Sakamoto (2008), Freshwater impacts recorded in tetraunsaturated alkenones and alkenone sea surface temperatures from the Okhotsk Sea across millennial-scale cycles, Paleoceanography, 23(3), PA2212.

Hendy, I. L. (2010), The paleoclimatic response of the Southern Californian Margin to the rapid climate change of the last $60 \mathrm{ka}$ : A regional overview, Quaternary $=$ International, 215(1-2), 62-73.

Hendy, I. L., and T. Cosma (2008), Vulnerability of the Cordilleran Ice Sheet to iceberg calving during late Quaternary rapid climate change events, Paleoceanography, 23(2), PA2101.

Hendy, I. L., and J. P. Kennett (2000), Dansgaard-Oeschger Cycles and the California Current System: Planktonic foraminiferal response to rapid climate change in Santa Barbara Basin, Ocean Drilling Program Hole 893A, Paleoceanography, 15(1), 30-42.

Hendy, I. L., and J. P. Kennett (2003), Tropical forcing of North Pacific intermediate water distribution during Late Quaternary rapid climate change?, Quaternary Science Reviews, 22(5-7), 673-689.

Hendy, I. L., J. P. Kennett, E. B. Roark, and B. L. Ingram (2002), Apparent

synchroneity of submillennial scale climate events between Greenland and Santa Barbara Basin, California from 30-10 ka, Quaternary Science Reviews, $21,1167-1184$.

Hendy, I. L., and T. F. Pedersen (2005), Is pore water oxygen content decoupled from productivity on the California Margin? Trace element results from Ocean 
Drilling Program Hole 1017E, San Lucia slope, California, Paleoceanography, 20(4), PA4026.

Hendy, I. L., T. F. Pedersen, J. P. Kennett, and R. Tada (2004), Intermittent existence

of a southern Californian upwelling cell during submillennial climate change of the last $60 \mathrm{kyr}$, Paleoceanography, 19(3), PA3007.

Hickey, B. M., and N. S. Banas (2008), Why is the northern end of the California Current system so productive?, Oceanography, 21(4), 90-107.

Jonkers, L., P. Jiménez-Amat, P. G. Mortyn, and G.-J. A. Brummer (2013), Seasonal $\mathrm{Mg} /$ Ca variability of N. pachyderma (s) and G. bulloides: Implications for seawater temperature reconstruction, Earth and Planetary Science Letters, $376,137-144$.

Justino, F., A. Timmermann, U. Merkel, and E. P. Souza (2005), Synoptic

Reorganization of Atmospheric Flow during the Last Glacial Maximum, Journal of Climate, 18, 2826-2845.

Keigwin, L. D., and E. A. Boyle (1989), Late Quaternary paleochemistry of highlatitude surface waters Palaeogeography, Palaeoclimatology, Palaeoecology(73), 85-106.

Kennett, J. P., E. B. Roark, K. G. Cannriato, B. L. Ingram, and R. Tada (2000), Latest Quaternary paleoclimatic and radiocarbon chronology, Hole 1017E, Southern California margin Proceedings of the Ocean Drilling Program, Scientific Results, $167,249-254$.

Kienast, S. S., S. E. Calvert, and T. F. Pedersen (2002), Nitrogen isotope and productivity variations along the northeast Pacific margin over the last 120 
kyr: Surface and subsurface paleoceanography, Paleoceanography, 17(4), 7$1-7-17$.

Kienast, S. S., and J. L. McKay (2001), Sea Surface Temperatures in the Subarctic Northeast Pacific Reflect Millennial-Scale Climate Oscillations during the Last 16 kyrs, Geophysical Research Letters, 28(8), 1563-1566.

Kim, S.-T., and J. R. O'Neil (1997), Equilibrium and nonequilibrium oxygen isotope effects in synthetic carbonates, Geochimica et Cosmochimica Acta, 61(16), 3461-3475.

Kuroyanagi, A., and H. Kawahata (2004), Vertical distribution of living planktonic foraminifera in the seas around Japan, Marine Micropaleontology, 53(1-2), 173-196.

Leduc, G., L. Vidal, K. Tachikawa, F. Rostek, C. Sonzogni, L. Beaufort, and E. Bard (2007), Moisture transport across Central America as a positive feedback on abrupt climatic changes, Nature, 445(7130), 908-911.

Leduc, G., L. Vidal, K. Tachikawa, and E. Bard (2009), ITCZ rather than ENSO signature for abrupt climate changes across the tropical Pacific?, Quaternary Research, 72(1), 123-131.

Leduc, G., L. Vidal, K. Tachikawa, and E. Bard (2010), Changes in Eastern Pacific ocean ventilation at intermediate depth over the last $150 \mathrm{kyr}$ BP, Earth and Planetary Science Letters, 298, 217-228.

LeGrande, A. N., and G. A. Schmidt (2006), Global gridded data set of the oxygen isotopic composition in seawater, Geophysical Research Letters, 33(12), L12604.

This article is protected by copyright. All rights reserved. 
Liu, K.-K., and I. R. Kaplan (1989), The eastern tropical Pacific as a source of 15Nenriched nitrate in seawater off southern California, Limnology and Oceanography, 34, 820-830.

Lynn, R. J., and J. L. Simpson (1987), The California Current system: The seasonal variability of its physical characteristics, Journal of Geophysical Research,

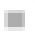
92(C12), 12947-12966.

Manabe, S., and R. J. Stouffer (1988), Two stable equilibria of a coupled oceanatmosphere model, Journal of Climate, 1, 841-866.

Marchitto, T. M., W. B. Curry, J. Lynch-Stieglitz, S. P. Bryan, K. M. Cobb, and D. C. Lund (2014), Improved oxygen isotope temperature calibrations for cosmopolitan benthic foraminifera, Geochimica et Cosmochimica Acta, 130(C), 1-11.

Martin, P. A., and D. W. Lea (2002), A simple evaluation of cleaning procedures on fossil benthic foraminiferal Mg/Ca, Geochemistry Geophysics Geosystems, 3(10), 8401.

Masson, D., and P. F. Cummins (1999), Numerical simulations of a buoyancy-driven coastal countercurrent off Vancouver Island, Journal of Physical Oceanography, 29, 418-435.

Masson, D., and I. Fine (2012), Modeling seasonal to interannual ocean variability of coastal British Columbia, Journal of Geophysical Research, 117(C10), C10019.

Max, L., J.-R. Riethdorf, R. Tiedemann, M. Smirnova, L. Lembke-Jene, K. Fahl, D. Nurnberg, A. Matul, and G. Mollenhauer (2012), Sea surface temperature variability and sea-ice extent in the subarctic northwest Pacific during the past 15,000 years, Paleoceanography, 27(3), PA3213. 
Meinvielle, M., and G. C. Johnson (2013), Decadal water-property trends in the California Undercurrent, with implications for ocean acidification, Journal of Geophysical Research: Oceans, 118(12), 6687-6703.

Mix, A. C., D. C. Lund, N. G. Pisias, P. Bodén, L. Bornmalm, M. Lyle, and J. Pike (1999), Rapid climate oscillations in the northeast Pacific during the last deglaciation $=$ reflect Northern and Southern Hemisphere sources, Mechanisms of global climate change at millennial time scales, 127-148.

Mosher, D. C., and A. T. Hewitt (2004), Late Quaternary deglaciation and sea-level history of eastern Juan de Fuca Strait, Cascadia, Quaternary International, 121, 23-39.

Ohkushi, K., J. P. Kennett, C. M. Zeleski, S. E. Moffitt, T. M. Hill, C. Robert, L. Beaufort, and R. J. Behl (2013), Quantified intermediate water oxygenation history of the NE Pacific: A new benthic foraminiferal record from Santa Barbara basin, Paleoceanography, 28(3), 453-467.

Okumura, Y. M., C. Deser, A. Hu, A. Timmermann, and S.-P. Xie (2009), North Pacific climate response to freshwater forcing in the subarctic North Atlantic: Oceanic and atmospheric pathways, Journal of Climate, 22(6), 1424-1445.

Pak, D. K., D. W. Lea, and J. P. Kennett (2004), Seasonal and interannual variation in Santa Barbara Basin water temperatures observed in sediment trap foraminiferal Mg/Ca, Geochemistry Geophysics Geosystems, 5(12), Q12008.

Pak, D. K., D. W. Lea, and J. P. Kennett (2012), Millennial scale changes in sea surface temperature and ocean circulation in the northeast Pacific, 10-60 kyr BP, Paleoceanography, 27(1), PA1212. 
Pausata, F. S. R., C. Li, J. J. Wettstein, M. Kageyama, and K. H. Nisancioglu (2011), The key role of topography in altering North Atlantic atmospheric circulation during the last glacial period, Climate of the Past, 7(4), 1089-1101.

Praetorius, S. K., and A. C. Mix (2014), Synchronization of North Pacific and Greenland climates preceded abrupt deglacial warming, Science, 345(6195),

= 444-448.

Reimer, P. J., et al. (2013), INTCAL13 and MARINE13 radiocarbon age calibration curves 0-50,000 years cal BP, Radiocarbon, 55(4), 1869-1887.

Riethdorf, J.-R., L. Max, D. Nurnberg, L. Lembke-Jene, and R. Tiedemann (2013), Deglacial development of (sub) sea surface temperature and salinity in the subarctic northwest Pacific: Implications for upper-ocean stratification, Paleoceanography, 28(1), 91-104.

Sautter, L. R., and R. C. Thunell (1989), Seasonal succession of planktonic foraminifera: Results from a four-year time-series sediment trap experiment in the Norteast Pacific, Journal of Foraminiferal Research, 19, 253-267.

Schrag, D. P., G. Hampt, and D. W. Murray (1996), Pore fluid constraints on the temperature and oxygen isotopic composition of the glacial ocean, Science, 272(5270), 1930-1932.

Seki, 0. (2002), Millennial climate oscillations in NE Pacific surface waters over the Iast 82 kyr: New evidence from alkenones, Geophysical Research Letters, 29(23), 2144. 
Shackleton, N. J. (1974), Attainment of isotopic equilibrium between ocean water and the benthonic foraminifera genus Colloques Internationaux du C.N.R.S., 219, 203-209.

Strub, P. T., and C. James (2002), Altimeter-derived surface circulation in the largescale NE Pacific Gyres. Part 1. seasonal variability, Progress In Oceanography,

$=$ $53,163-183$.

Sydeman, W. J., S. A. Thompson, J. C. Field, W. T. Peterson, R. W. Tanasichuk, H. J. Freeland, S. J. Bograd, and R. R. Rykaczewski (2011), Does positioning of the North Pacific Current affect downstream ecosystem productivity?, Geophysical Research Letters, 38(12), L12606.

Taylor, M. A., I. L. Hendy, and D. K. Pak (2014), Deglacial ocean warming and marine margin retreat of the Cordilleran Ice Sheet in the North Pacific Ocean, Earth and Planetary Science Letters, 403, 89-98.

Thomson, R. E., and M. V. Krassovski (2010), Poleward reach of the California Undercurrent extension, Journal of Geophysical Research, 115(C9), C09027. Timmermann, A., F. Justino, F. F. Jin, U. Krebs, and H. Goosse (2004), Surface temperature control in the North and tropical Pacific during the last glacial maximum, Climate Dynamics, 23(3-4).

Waelbroeck, C., L. Labeyrie, E. Michel, J. C. Duplessy, J. F. McManus, K. Lambeck, E. Balbon, and M. Labracherie (2002), Sea-level and deep water temperature changes derived from benthic foraminifera isotopic records, Quaternary Science Reviews, 21, 295-305. 
Zhang, R., and T. L. Delworth (2005), Simulated tropical response to a substantial weakening of the Atlantic thermohaline circulation, Journal of Climate, 18, 1853-1860.
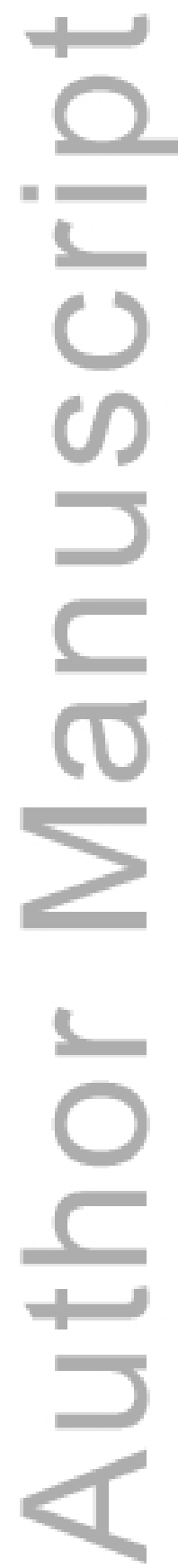

This article is protected by copyright. All rights reserved. 


\section{Figure Captions}

Figure 1.

Location of core sites (black circle, this study) MD02-2496 (4858'48”N,

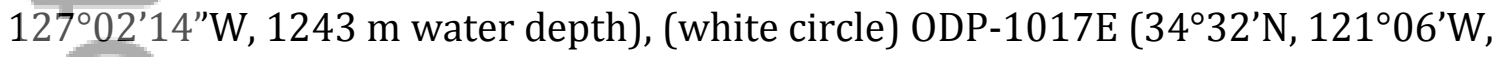

966 m water depth) (Pak et al., 2012; Hendy, 2010), and (grey circle) ODP-893A

(Hendy and Kennett, 2000) (341'15”N, 12002'12”W, 576.5 m water depth) along

the northeastern Pacific margin. Dashed lines indicate annual average SSTs (Auad et

al., 2011). Arrows represent dominant modern current configurations, where the light grey arrows represent the North Pacific Current. The California Current (dark grey arrow) extends from the continental slope to $\sim 1000 \mathrm{~km}$ offshore. The dashed grey arrow represents the core flow of the California Undercurrent, along the shelf break and at 200-300 m depth and upwelled onto the shelf.

Figure 2.

Age in calendar years B.P. versus core depth (corrected $\mathrm{cm}$ below core top). Age model was generated using calibrated mixed planktonic species and bulk organic carbon (purple marks) radiocarbon dates (Cosma et al., 2008). The previously published radiocarbon dates were recalibrated using the MARINE13 calibration (Reimer et al., 2013). The age model (red dotted line) is a Bayesian interpolation between dates generated with Monte Carlo simulated age model errors (width of black line) using Bacon 2.2 (Blaau and Christen, 2011).

Figure 3.

This article is protected by copyright. All rights reserved. 
Top panel (A) NGRIP $\delta^{18} \mathrm{O}$ (black line) and DOIs numbered in red and shaded in gray (NGRIP members, 2004; Blockley et al., 2012). For panels B-I, G. bulloides samples are red and N. pachyderma samples are blue. Shaded envelopes represent running (1 kyr) standard deviation of samples. Measured $\mathrm{Mg} / \mathrm{Ca}$ of the planktonic foraminifera species (B) G. bulloides and (C) N. pachyderma. Calculated SSTs for G. (1)

bulloides (D) and N. pachyderma (E), and calculated $\delta^{18} \mathrm{O}_{\text {seawater }}$ for G. bulloides (F) and for $N$. pachyderma (G). Bottom panels show $\delta^{18} \mathrm{O}_{\text {calcite }}$ for G. bulloides $(\mathrm{H})$ and $N$. pachyderma (I) (Hendy and Cosma, 2008) with calibrated radiocarbon tie points (black circles) and age model error calculated from Bacon 2.2 (Blaauw and Christen, 2011) marked along the bottom axis.

Figure 4.

Top panel (A) NGRIP $\delta^{18} \mathrm{O}$ (black line) and DOIs numbered in red and shaded in gray (NGRIP members, 2004; Blockley et al., 2012). Reconstructed SSTs (B) and $\delta^{18} \mathrm{O}_{\text {seawater }}$ (C) from G. bulloides (red circles) at site ODP-1017E, Point Conception, CA (Pak et al., 2012). Reconstructed SSTs (D) and $\delta^{18} 0_{\text {seawater }}$ (E) from G. bulloides (red circles) from core site MD02-2496 are plotted in red circles. Reconstructed SSTs (F) and $\delta^{18} \mathrm{O}_{\text {seawater }}(\mathrm{G})$ from N. pachyderma (blue circles). For B-I black lines represent a 300 year resampling of data (resampled by simple linear interpolation). Calibrated radiocarbon tie points (black circles) and age model error calculated from Bacon 2.2 (Blaauw and Christen, 2011) are marked along the bottom axis.

Figure 5.

This article is protected by copyright. All rights reserved. 
All panels (A-E) normalized to zero mean and unit variance. Top panel (A) NGRIP $\delta^{18} \mathrm{O}$ (black line) and DOIs numbered in red and shaded in gray, and Heinrich events are numbered in blue (NGRIP members, 2004; Blockley et al., 2012). Unit variance normalized N. pachyderma data are shown in blue where B) is N. pachyderma $\delta^{18} \mathrm{O}_{\text {calcite }}($ Hendy and Cosma, 2008), (C) N. pachyderma SST, (D) N. pachyderma $\delta^{18} \mathrm{O}_{\text {seawater }}$ and (E) is normalized $\delta^{15} \mathrm{~N}$ of bulk sediments (green line) (Chang et al., 2012) from MD02-2496. Black lines are a 1 kyr running average. Calibrated radiocarbon tie points (black circles) and age model error calculated from Bacon 2.2 (Blaauw and Christen, 2011) marked along the bottom axis.

Figure 6.

Top panel (A) NGRIP $\delta^{18} \mathrm{O}$ (black line) and DOIs numbered in red and shaded in gray (NGRIP members, 2004; Blockley et al., 2012). A running cross correlation (B) was measured between $N$. pachyderma SST and N. pachyderma $\delta^{18} \mathrm{O}_{\text {calcite }}$ (Hendy and Cosma, 2008) and (C) between $\delta^{15} \mathrm{~N}$ of bulk sediments and $N$. pachyderma $\delta^{18} \mathrm{O}_{\text {calcite. }}$. Records were resampled by simple linear interpolation at 300-years and correlations were calculated with a 2.4 ka moving window (black line). Monte Carlo simulations estimated significance where correlations were found to be $95 \%$ significant at \pm 0.92 or higher (solid red line) and $99 \%$ significant at \pm 0.95 or higher (dashed red line). Calibrated radiocarbon tie points (black circles) and age model error calculated from Bacon 2.2 (Blaauw and Christen, 2011) marked along the bottom axis. 


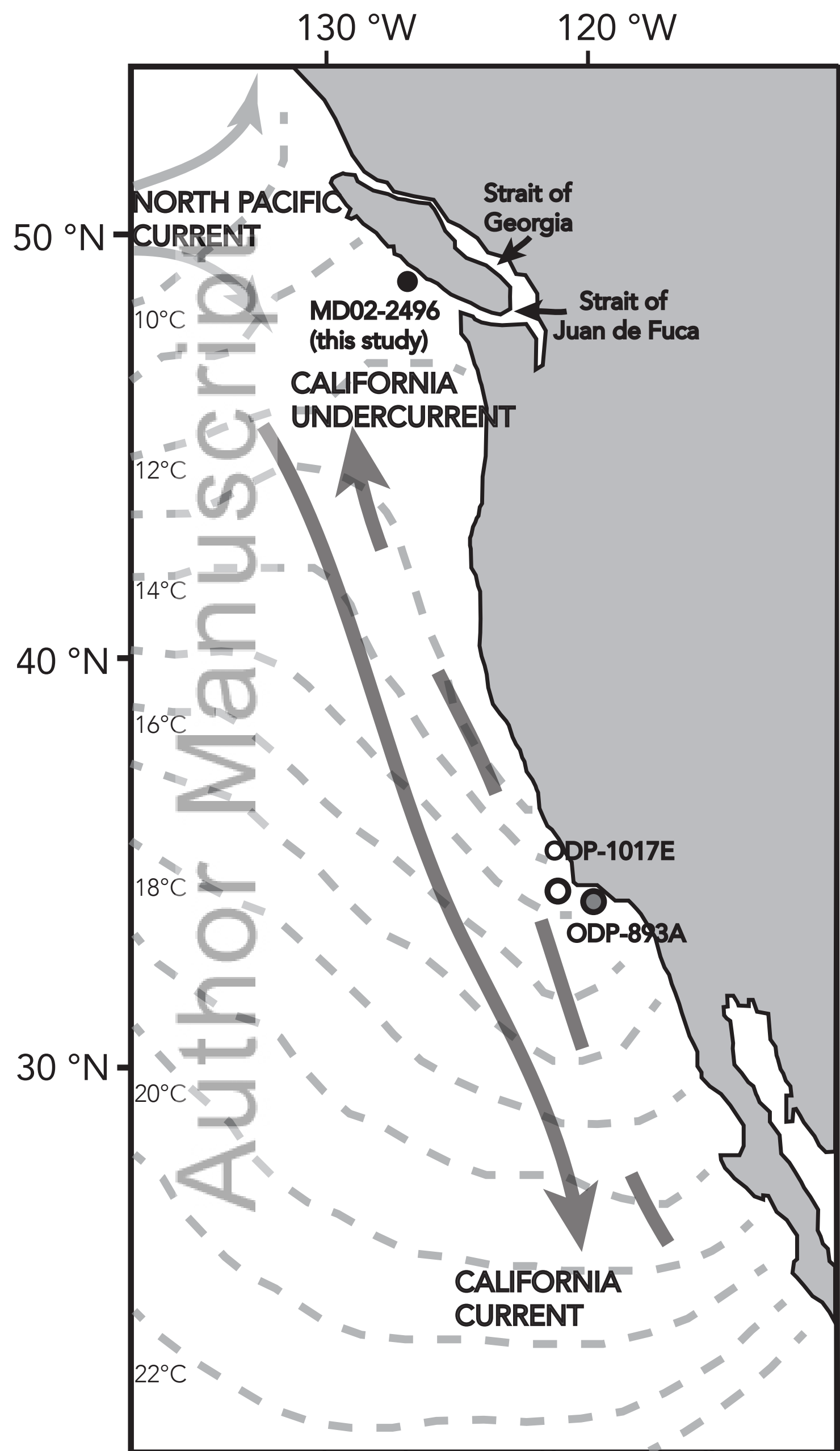

This article is protected by copyright. All rights reserved. 


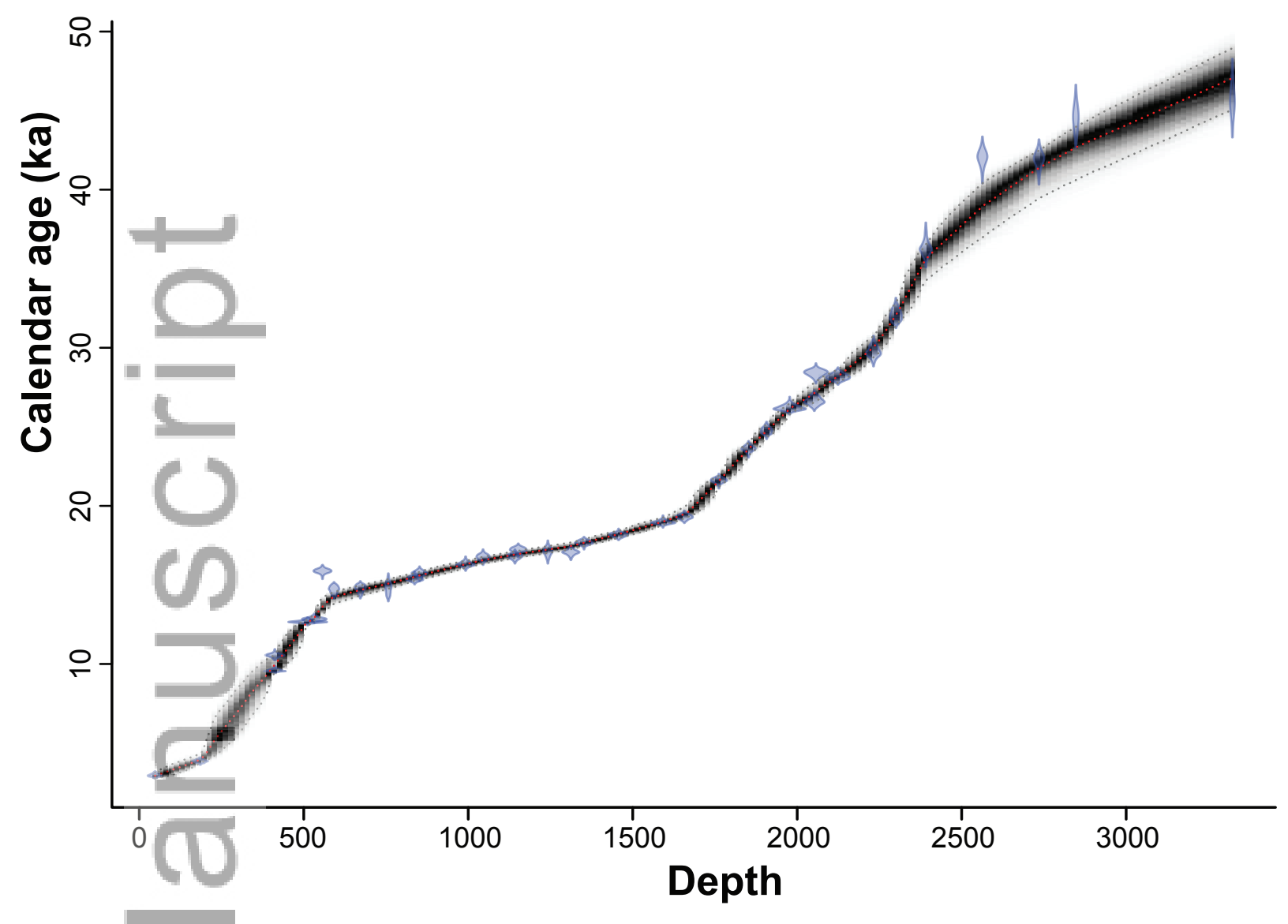

This article is protected by copyright. All rights reserved. 

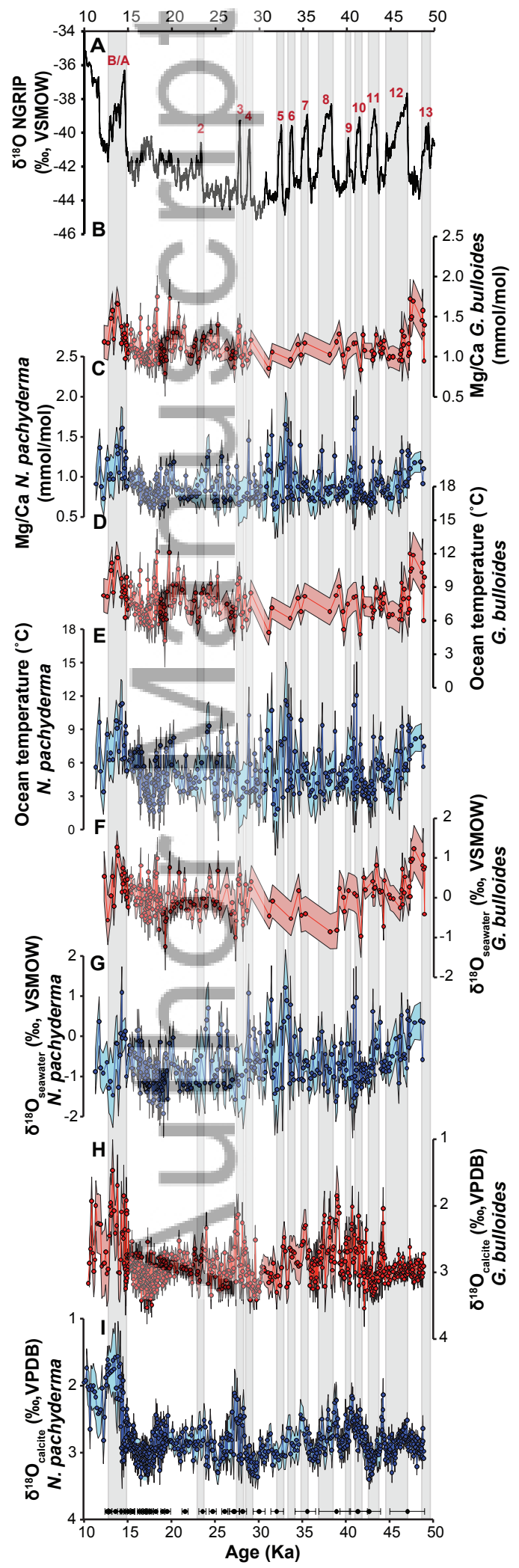

This article is protected by copyright. All rights reserved. 


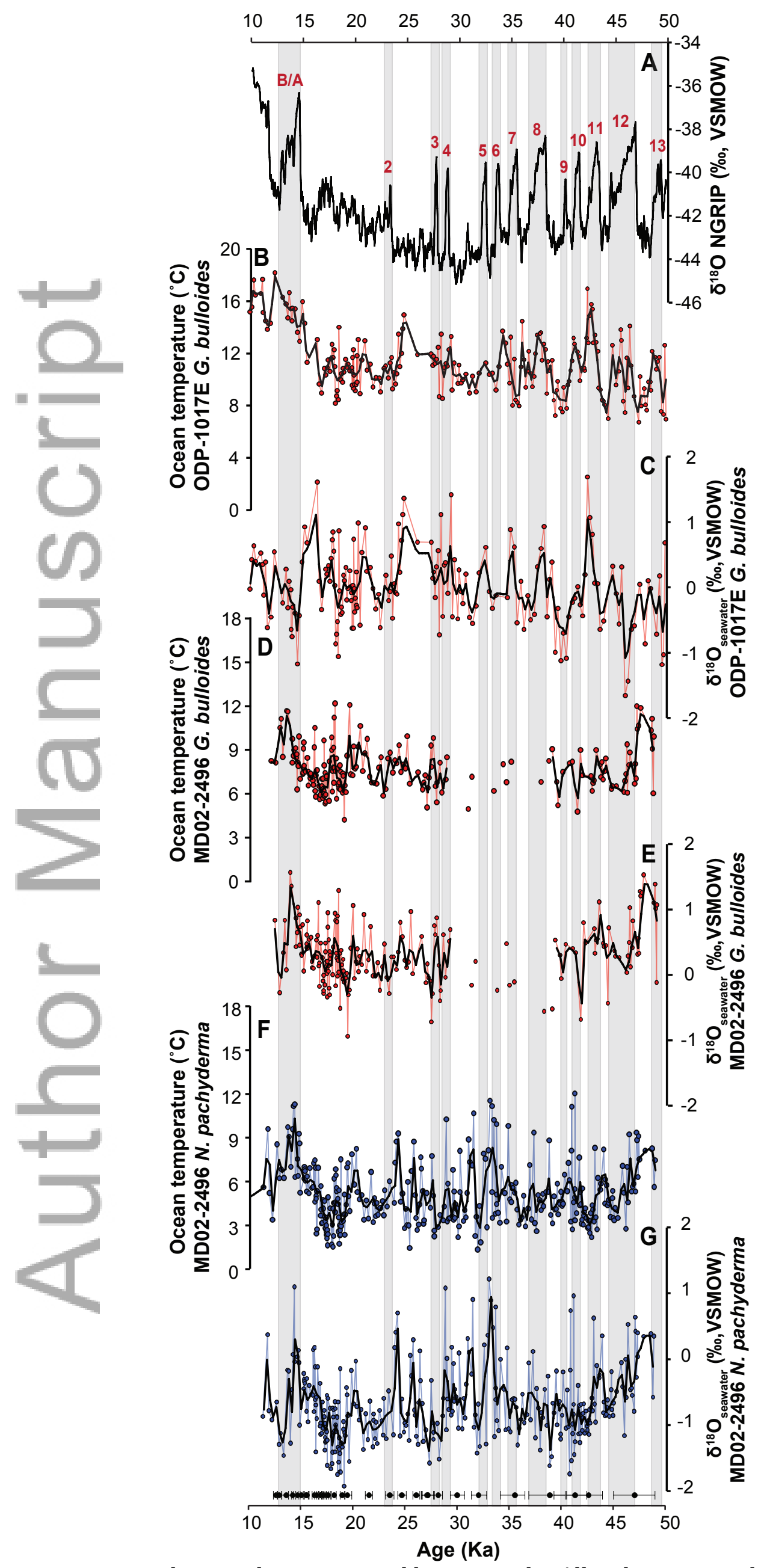

This article is protected by copyright. All rights reserved. 


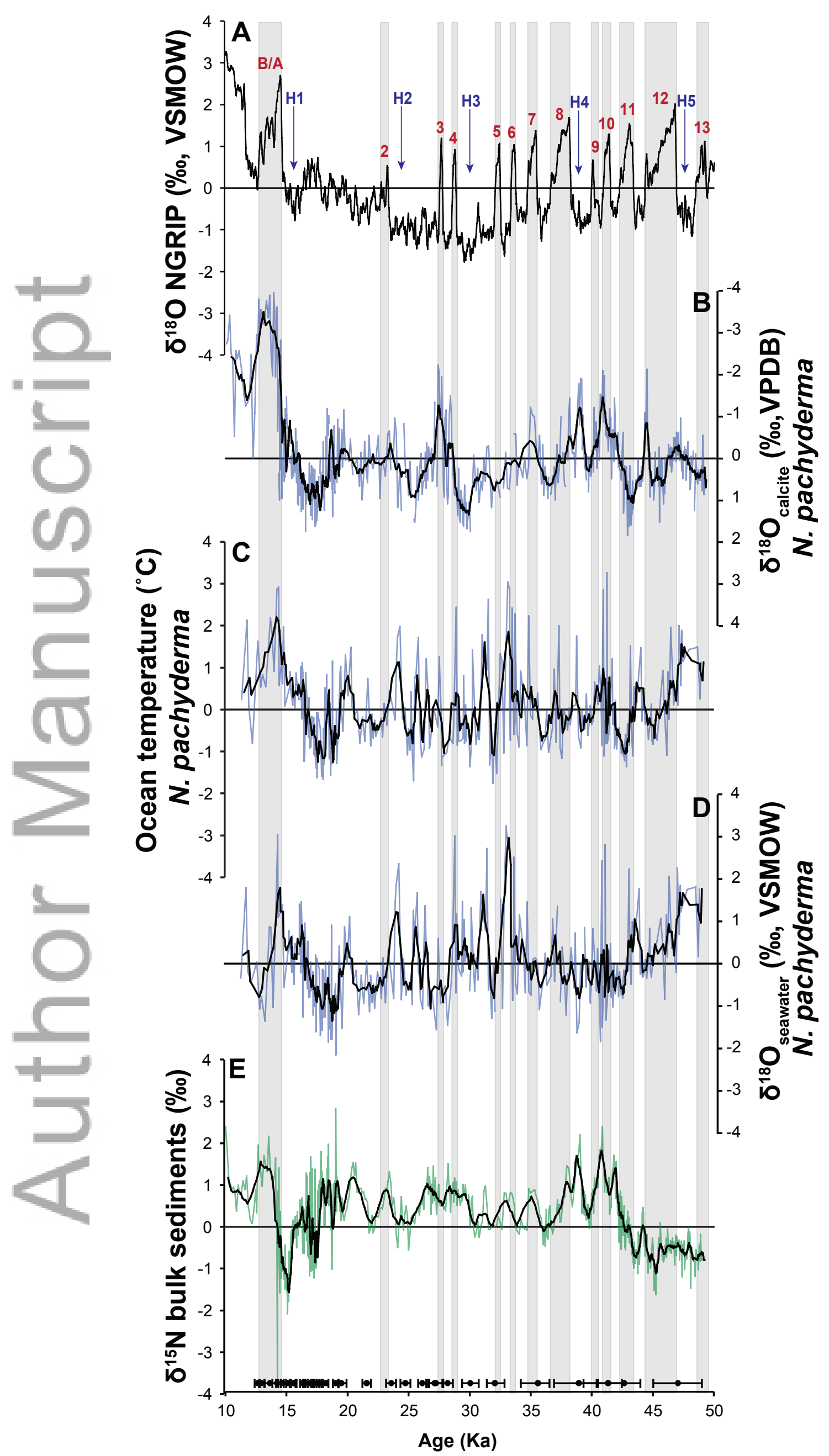

This article is protected by copyright. All rights reserved. 


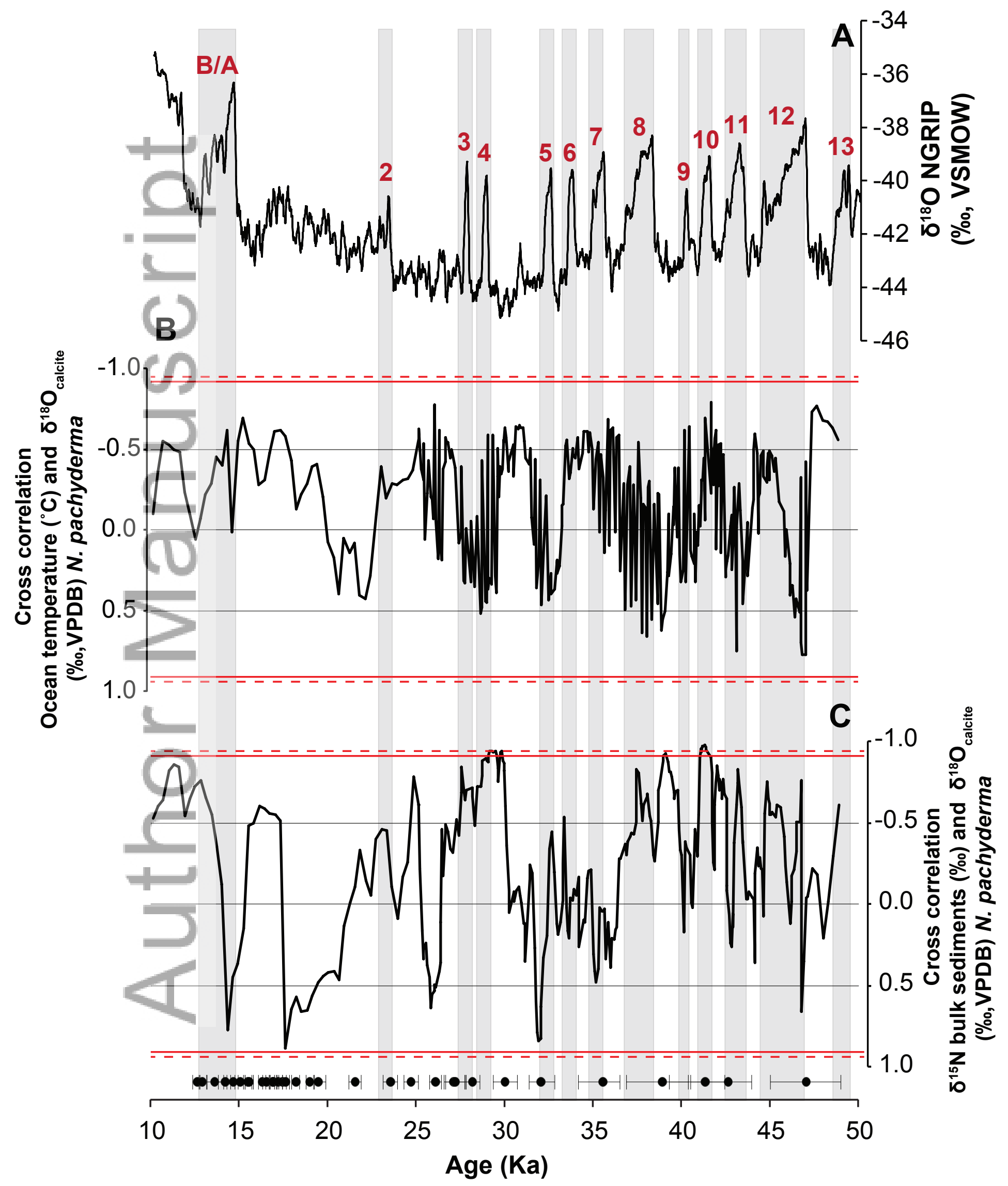

This article is protected by copyright. All rights reserved. 